$\xi=-1$

\title{
Contractor Selection Criteria: a Study on Malaysian Public Construction Projects
}

\author{
Izwan Rashid ${ }^{1 *}$, Syuhaida Ismail², Zainai Mohamed ${ }^{3}$, Abd. Latif Saleh ${ }^{4}$ \\ ${ }^{1,2,3}$ UTM Razak School of Engineering and Advanced Technology, Universiti Teknologi Malaysia, Kuala Lumpur, Malaysia. \\ ${ }^{4}$ Faculty of Civil Engineering, Universiti Teknologi Malaysia, Johor Bahru, Malaysia. \\ *Corresponding author E-mail: izwan.utmkl@gmail.com
}

\begin{abstract}
The complexity of a construction project renders the implementation of a systematic approach in selecting contractors to be of vital importance, especially for the public construction projects. Nevertheless, public construction projects in Malaysia often suffer from delay, over budget and low-quality issues. These are very much affected by the contractors who tend to manipulate the tender price with the sole intention of getting the contract, thus led to many issues throughout the projects delivery. Hence, this paper is aimed to investigate a list of contractor selection criteria for public construction projects in Malaysia. A total of 43 selection criteria have been identified and categorised into seven categories from an initial review via content analysis. These findings were then verified via a questionnaire survey, which was responded by 276 local Malaysian construction industry practitioners. Data collected were analysed using the IBM Statistical Package of Social Sciences (SPSS). The analysis showed that all 43 selection criteria were significant in selecting contractors. It is hoped that the findings of this paper would encourage the governing bodies and authorities to consider the use of multi criteria assessment in selecting contractors for public construction projects, rather than being solely reliant on the tendered price.
\end{abstract}

Keywords: Contractor Selection; Selection Criteria; Construction Projects; Public Projects; Malaysia.

\section{Introduction}

The impact of contractors on project performance is significant; a prequalified and well selected contractor has the potential of delivering projects of the acceptable quality standard within the allocated period [1]. This can eliminate unnecessary expenditure that can considerably burden the project funding. Furthermore, the process of qualification and selection of a contractor is a very complex decision-making task, whereby failure to perform it may possibly cause delays, culminate in large losses, or pose severe harm to the project quality [2]. Such implications further reflect the complicated and critical aspect of the selection process. Hence, this paper suggests that contractors should be evaluated from various angles, and not solely according to the priced offered.

Over the past few years, contractor selection has been a topic of much interest and awareness within the construction management research community [3]. With the final goal of developing a contractor selection framework, this paper aims to investigate the selection criteria that are contributing to project success which will be incorporated with the comprehensive assessment of key attributes required in a contractor. [4] have highlighted that these elements play a big role towards project performance and success. Therefore, selecting the best contractor for projects is the biggest challenge during the decision-making process. This specific challenge can be overcome by yielding a review of contractor selection criteria for construction projects and its establishment as a standardised reference in the future.

\section{Literature review}

\subsection{Construction Project}

Construction activities and industry are one of the key foundations for economic development and national growth [5]. The industry has evolved over the time to become more vital, matured and complicated in the recent years. According to [6], its influence towards economic expansion and long-term national development is undeniable, particularly in developing countries. In fact, a country's industrial growth is an informal indicator of its economic growth.

Therefore, managing projects in the construction industry is a challenging and daunting task for many due to cost, time and quality constraints. Large engineering construction projects are made up of various resources, which includes labour, materials, and equipment; they involve planning and strategising to ensure effective operations and the resulting economic advantage [7]. Most projects are of unique due to the involvement of various parties with conflicting interests, resulting in the issues of over-budgeting, time extensions and conflicts among parties if not managed properly. Furthermore, construction project management is increasingly complex, necessitating the implementation of proper project management knowledge practices in organisations. This will be discussed further in the following section 


\subsection{Overview of Project Management}

The complexity of construction projects has caused for the concept of project management to emerge, which has been initially introduced in the 1950's [8]. Project management has been described by [9] as the application of knowledge, skills, tools, and techniques to project activities to meet the project requirements. On the other hand, [10] has defined it further as the application of processes, methods, knowledge, skills, and experience to achieve project objectives. Both organisations are respectable and acknowledged authorities on project management, rendering their definitions parallel and universally acceptable. Many project management theories and models have been subsequently developed over time by many parties as the ways to execute tasks have also changed accordingly. Organisational performance of projects has concomitantly changed over the years, encompassing the breaking down of work into tasks, activities scheduling, cost controls and allocation of resources. Nowadays, the concept of project management has expanded to almost all industries, particularly the construction industry.

Thus, the element of project management is undoubtedly critical in a construction project. Systematic management poses a constructive effect by allowing the completion of the project within the specified time, quality, and budget. However, effective project management can be implemented with the mastery of several areas of knowledge. According to [11], there are 12 knowledge areas with relation to the construction industry. They are Project Integration Management, Project Scope Management, Project Schedule Management, Project Cost Management, Project Quality Management, Project Resource Management, Project Communication Management, Project Risk Management, Project Procurement Management, Project Stakeholder Management, Project Health, Safety, Security and Environmental Management, as well as Project Financial Management.
In the context of project procurement management in the construction industry especially, contractor selection process is an essential process to be undertaken. Due to the primary responsibility of contractors in handling the main activities, the project success and achievement is heavily dependent on the selection of a capable contractor [12]. Thus, it is important for the project owner or consultant to identify and allocate projects to appropriate contractor.

\subsection{Contractor Selection Criteria}

Construction activities are generally prone to risks, which affect the final project performance. Therefore, a construction client must ensure that the most crucial task of selecting a suitable contractor is successfully carried out to achieve an acceptable project result. Comparing bid prices is a commonly done practice in many organisations and oftentimes the only criterion when selecting contractors, which has often been subjected to criticisms. The lowest bidding price may not inevitably benefit the client as the quality and period of the project may be undermined [13] [14]. [15 have stated that bid evaluation by contractors may implicate the comparison of different criteria assessed according to different gauges, as different decision makers have different preferences. Thus, there is no general consensus on a common set of selection criteria for the selection of contractor according to the unique nature of each project.

Previous literature has highlighted various contractor selection criteria, but in a real practice setting, clients will nevertheless possess their own different criteria. This part of the literature review is focused on identifying critical selection criteria for selecting contractors for construction projects. Content analysis on previous related studies has yielded the generalised categorisation of contractor selection criteria into seven main categories. They include management capability, financial capacity, experience, resources, technical, environmental health and safety (EHS) and others. The classification has been summarised in Table 1.

Table1: Summary of Contractor Selection Criteria

\begin{tabular}{|c|c|c|c|}
\hline No. & Category & Contractor Selection Criteria & References \\
\hline 1. & Management Capability & $\begin{array}{l}\text { - Client-contractor relationship } \\
\text { - Reputation } \\
\text { - Project management } \\
\text { - Company management } \\
\text { - Client satisfaction } \\
\text { - Length of time in business }\end{array}$ & {$[3],[12],[15]-[20]$} \\
\hline 2. & Financial Capacity & $\begin{array}{l}\text { - Financial condition } \\
\text { - Financial guarantee } \\
\text { - Company assets } \\
\text { - Credit rating } \\
\text { - Cash in hand } \\
\text { - Financial management } \\
\text { - Company turnover } \\
\text { - Liability }\end{array}$ & {$[3],[12],[15]-[19],[21],[22]$} \\
\hline 3. & Experience & $\begin{array}{l}\text { - Past job performance } \\
\text { - Past similar experience } \\
\text { - Staff experience } \\
\text { - Experience in the region } \\
\text { - Past failure } \\
\text { - Size of past projects } \\
\text { - Number of past projects }\end{array}$ & {$[3],[12],[15]-[22]$} \\
\hline 4. & Resources & $\begin{array}{l}\text { - Equipment and tools } \\
\text { - Technical manpower } \\
\text { - Project in hand } \\
\text { - Number of staff } \\
\text { - Progress of existing projects } \\
\text { - Machinery }\end{array}$ & {$[12],[15],[17]-[22]$} \\
\hline 5. & Technical & $\begin{array}{l}\text { - Company competency } \\
\text { - Staff qualification } \\
\text { - Quality management } \\
\text { - Staff competency } \\
\text { - Work method } \\
\text { - Technology }\end{array}$ & {$[3],[15]-[22]$} \\
\hline
\end{tabular}




\begin{tabular}{|c|c|c|c|}
\hline & & - Quality assurance & \\
\hline 6. & Environmental, Health and Safety & $\begin{array}{l}\text { - Health and Safety Management } \\
\text { - Environmental Management } \\
\text { - Health and Safety Experience } \\
\text { - Accident Rate } \\
\text { - Safety Rate }\end{array}$ & {$[3],[12],[15]-[17],[19]$} \\
\hline 7. & Others & $\begin{array}{l}\text { - Time completion } \\
\text { - Risk management } \\
\text { - Political consideration }\end{array}$ & [3], [12], [16], [19] \\
\hline
\end{tabular}

\section{Methodology}

With the aim of this paper to investigate the effectiveness of the price-based evaluation system and industry player's perspective on the current method of selecting contractors, a survey is constructed based on the quantitative research approach. It uses a purposive sample, which [23] describe as "handpicked sample". In selecting the sample for this study, it is important to ensure that the sample selected could provide information needed.

\subsection{Data Sample}

In view of this paper which is focusing on the bid and tender assessment for public construction projects in Malaysia, the sample is among the local Malaysian construction industry practitioners, including engineers, architects, quantity surveyors, contractors and most importantly public agency officers, who are related to the delivery of public construction projects. These groups of people are expected to have first-hand information and experience in the industry. Anyhow, due to different project environment and geographical distance between Peninsular Malaysia and Sabah and Sarawak, this study is limited to the contractors for public construction projects in Peninsular Malaysia. With this group of targeted population in mind, it is difficult to estimate the actual population size. Therefore, referring to [24], 384 samples are targeted. Since the nature of this paper is exploratory and the size of the sample is large, a more convenience and economical survey approach is being utilised. The online survey is conducted since it is more cost saving and can be done quickly [25]. Approximately 400 invitations were sent through emails and social media, targeting the said populations.

\subsection{Questionnaire}

The main questionnaire consists of three sections. The first section gathers respondents' personal information, the second section investigates stakeholders' perception on the effectiveness of current tender evaluation system for public construction projects in Malaysia and the last section examines critical selection criteria for evaluating contractors for public construction projects in Malaysia. For this paper, only selected sections of the questionnaire related to the topic are discussed. The questionnaire survey was designed to apprehend the respondents' responses, where respondents were given with a statement, and then they were requested to provide their replies with variable degrees of agreement or disagreement scales. Respondents attitudes are measured using the 5points Likert scale ranging from "1" (strongly disagreed) to "5" (strongly agreed).

\subsection{Relative Importance Index (RII)}

To mathematically determine the importance level of each contractor selection criteria, the Relative Importance Index (RII) analysis is employed. RII is a form of relative importance analyses. RII is used for the analysis because it best fits the purpose of this study. This calculation method was used by [26], where RII is calculated to quantify project delay factor. [27] also adopted the same method, where the Procrastination Factors among university students are ranked. Furthermore, [28] used the same approach in the study of contractor selection. Therefore, since this study shares the multi-attributes characteristics with those studies, a similar method is used in this study. The equation to calculate RII for each item is shown as in (1).

Relative Importance Index $=\left(\sum \mathrm{W}\right) /\left(\mathrm{A}^{*} \mathrm{~N}\right)$

Where,

$\mathrm{W}=$ weighting given to each item by each respondent

A $\quad=$ highest available weight

(in this study it is 5 to represent 'strongly agreed')

$\mathrm{N}=$ total number of respondents

The RII value will have a range of $0>\mathrm{RII} \leq 1$, where the higher the RII, the more important will the item be. The items are then ranked according to their respective RIIs. These rankings make it possible to compare the relative importance of each factor as alleged by the respondents. A table of contractor selection criteria arranged in terms of RII is used to assess and give an overall view of the importance of each item. This table helps to build the framework of contractor selection for public construction projects in Malaysia.

\section{Result and Findings}

From the 400 invitations sent, a number of 276 completed responses were received. This amount signifies a response rate of 69 percent. Since [29] suggested 37 percent threshold for online survey, the response received is considered very successful. The result of the survey is as follows.

\subsection{Demographic Data}

Table 2 represented the findings of the demographic data. Out of the total 276 respondents, 65.9 percent of the respondents are male, and remaining 34.1 percent are female respondents. It is commonly known that the construction industry is usually subjugated by males and this wide range of gap between males and females demonstrates the males' domination in the Malaysian construction industry. All respondents are between the age of 20 years old and above, where somewhat more than half of the respondents are in the range from 30 to 39 years old, 14.9 percent are of 20 to 29 years old, 23.5 percent are of 40 to 49 years old, and 8.7 percent are in their 40s. The high percentage of respondents aged between 30 and 39 years old demonstrates that the results are considered reliable as the responses are obtained from those respondents with significant years of working experience within the construction industry. Since all respondents come from several organisations pertaining to the Malaysian construction industry, the largest group are consultants who represent 45.7 percent of respondents, 33.3 percent works in various government agencies, 17.8 percent are contractors, and only 3.2 percent comes from other types of organisation. 
Table2: Demographic Data

\begin{tabular}{|c|c|c|c|}
\hline Items & Details & $\mathrm{N}$ & $\begin{array}{c}\text { Valid Percentage } \\
(\%)\end{array}$ \\
\hline Gender & $\begin{array}{l}\text { Male } \\
\text { Female } \\
\text { Total }\end{array}$ & $\begin{array}{c}182 \\
94 \\
276\end{array}$ & $\begin{array}{l}65.9 \\
34.1 \\
100\end{array}$ \\
\hline Age & $\begin{array}{l}20-29 \text { years old } \\
30-39 \text { years old } \\
40-49 \text { years old } \\
>49 \text { years old } \\
\text { Total }\end{array}$ & $\begin{array}{c}41 \\
146 \\
65 \\
24 \\
276\end{array}$ & $\begin{array}{c}14.9 \\
52.9 \\
23.5 \\
8.7 \\
100\end{array}$ \\
\hline $\begin{array}{l}\text { Organisation } \\
\text { Type }\end{array}$ & $\begin{array}{l}\text { Government agency } \\
\text { Consultant } \\
\text { Contractor } \\
\text { Others } \\
\text { Total }\end{array}$ & $\begin{array}{c}92 \\
126 \\
49 \\
9 \\
276\end{array}$ & $\begin{array}{c}33.3 \\
45.7 \\
17.8 \\
3.2 \\
100\end{array}$ \\
\hline $\begin{array}{l}\text { Experience in } \\
\text { public projects }\end{array}$ & $\begin{array}{l}\text { Yes } \\
\text { No } \\
\text { Total }\end{array}$ & $\begin{array}{c}271 \\
5 \\
276\end{array}$ & $\begin{array}{c}98.2 \\
1.8 \\
100\end{array}$ \\
\hline
\end{tabular}

were cash in hand, product quality offered, price offered, time completion offered, experience in business, safety and health competency, financial management system, past achievement in job performance, client-contractor relationship and risk management system. It is observed in this paper that the top four contractors selection criteria as agreed by the Malaysian construction industry players are closely related to the "Project Management Triangle" of [9]: cost, scope, schedule, and quality, thus confirms that the contractors should not be merely selected based on the lowest cost offered alone.

On the other hand, the least top ten criteria were found to be quality control, familiarity with work location, staff qualification, financial guarantee, technology and work method, staff experience in industry, equipment, tools and machinery, company management system, technical manpower and quality management system. The quality management system is agreed to be the least agreed contractor selection criteria based on the fact that quality management system is implemented at a moderate level within the Malaysian construction industry as claimed by [30]. Besides, technical manpower is also agreed as least important because most of the contractors outsource its works to sub-contractors thus a shortage of technical manpower is not an issue [31]

\subsection{RII of Contractor Selection Criteria}

Table 3 demonstrated contractor selection criteria responded by the 276 respondents of the Malaysian construction industry. Based on the results, the most top ten priorities in selecting contractors

Table3: Summary result of descriptive analysis and Relative Importance Index (RII) of Contractor Selection Criteria

\begin{tabular}{|c|c|c|c|c|}
\hline Code & Indicator & Mean & SD & RII \\
\hline FC5 & Cash in hand & 4.63 & 0.63 & 1.272 \\
\hline TQC2 & Products quality offered & 4.59 & 0.59 & 1.130 \\
\hline TQC3 & Price offered & 4.58 & 0.58 & 1.108 \\
\hline MC6 & Experience in business & 3.16 & 0.50 & 0.527 \\
\hline EHS3 & Safety and health competency & 2.55 & 0.78 & 0.521 \\
\hline FC6 & Financial management system & 4.04 & 0.72 & 0.516 \\
\hline EX1 & Past achievement in job performance & 3.04 & 0.56 & 0.513 \\
\hline $\mathrm{MC1}$ & Client-contractor relationship & 2.79 & 0.62 & 0.506 \\
\hline MC7 & Risk management system & 3.12 & 0.52 & 0.500 \\
\hline EHS1 & Safety and health management system & 2.64 & 0.65 & 0.491 \\
\hline $\mathrm{MC} 2$ & Reputation & 2.42 & 0.58 & 0.481 \\
\hline FC3 & Company asset & 2.68 & 0.73 & 0.478 \\
\hline RS5 & Progress of existing projects & 2.52 & 0.62 & 0.478 \\
\hline RS3 & Projects in hand & 2.61 & 0.64 & 0.472 \\
\hline RS4 & Number of staff & 2.71 & 0.65 & 0.470 \\
\hline EHS2 & Environmental management system & 2.54 & 0.65 & 0.458 \\
\hline $\mathrm{FC} 4$ & Company liability & 2.34 & 0.68 & 0.457 \\
\hline TC4 & Project manager competency & 4.20 & 0.52 & 0.454 \\
\hline EX5 & Size of past projects & 2.64 & 0.73 & 0.454 \\
\hline RS6 & Vehicle & 2.59 & 0.64 & 0.451 \\
\hline TC7 & Quality assurance & 3.49 & 0.63 & 0.446 \\
\hline EX2 & Past failure in job performance & 2.41 & 0.68 & 0.445 \\
\hline EHS4 & Environmental competency & 2.53 & 0.71 & 0.444 \\
\hline MC3 & Project management system & 3.97 & 0.68 & 0.440 \\
\hline FC1 & Company yearly turnover & 2.44 & 0.75 & 0.439 \\
\hline MC5 & Client satisfaction & 2.22 & 0.51 & 0.435 \\
\hline EX7 & Number of past projects & 2.39 & 0.66 & 0.432 \\
\hline FC7 & Credit facility & 3.91 & 0.64 & 0.409 \\
\hline TC1 & Company registration & 3.51 & 0.61 & 0.388 \\
\hline EX3 & Past similar job scope & 3.40 & 0.55 & 0.385 \\
\hline EHS5 & Accident rate - "Lost time injury" & 2.08 & 0.68 & 0.367 \\
\hline TC2 & Staff qualification & 3.74 & 0.60 & 0.311 \\
\hline FC2 & Financial guarantee & 3.97 & 0.60 & 0.308 \\
\hline TC5 & Technology and work method & 3.81 & 0.59 & 0.298 \\
\hline
\end{tabular}




\begin{tabular}{|c|l|c|c|}
\hline EX6 & Staff experience in industry & 3.46 & 0.295 \\
\hline RS1 & Equipment, tools and machinery & 3.55 & 0.67 \\
\hline MC4 & Company management system & 3.74 & 0.55 \\
\hline RS2 & Technical manpower & 3.86 & 0.293 \\
\hline TC3 & Quality management system & 4.05 & 0.272 \\
\hline
\end{tabular}

Note: Mean = Mean Value; SD = Standard deviation; RII = Relative Importance Index

\section{Conclusion}

This paper has successfully achieved its aim of investigating critical contractor selection criteria for construction projects. From the literature review carried out via content analysis, it has been found that 43 criteria have been identified by previous researchers. These criteria have been subsequently divided into seven main categories, which are: management capability, financial capacity, experience, resources, technical ability, environmental, health and safety (EHS), and others. Nevertheless, further investigation is recommended, particularly in analysing and verify the ranking order of the contractor selection criteria for construction projects. This can be done using a more advanced multi criteria decision making methods, such as Analytical Hierarchy Process (AHP), Preference Ranking Organisation Method for Enrichment of Evaluations (PROMETHEE), Technique for Order of Preference by Similarity to Ideal Solution (TOPSIS), Multi-Attribute Utility Theory (MAUT) and others. Such attempt will assist clients and project owners to prioritise and subsequently establish their in-depth understanding of each criterion. Part of Malaysian government agenda in the Construction Industry Transformation Programme (CITP) is to transform the construction industry towards becoming highly productive and focuses on quality. It is always the main concern in conducting this study that it will have positive impacts on the construction industry, parallel with the CITP direction. This study intends to provide the industry with a standardised reference in selecting contractors for public construction projects. With a standard framework, it is hoped that there will be no conflict among different public organisations. Similar contractor selection process among different agencies could eradicate unethical conduct in selecting contractors for public construction projects. The proposed framework will help to eliminate non-performers, where only qualified contractors will be selected. With the result of this study, it is hoped that the quality of public construction project output can be enhanced. Time and cost over-run can also be improved. This will eventually improve the output efficiency of the industry and contribute indirectly to the country productivity.

\section{Acknowledgement}

The authors would like to express their sincere gratitude to the Ministry of Education Malaysia, Universiti Teknologi Malaysia (UTM) and the Research Management Centre (RMC) of UTM for providing the financial support for this paper to be published. This study is financed by the Grant for Research University (GUP) Tier 2 of UTM for research funding under Cost center No. Q.J130000.2605.12J08.

\section{References}

[1] I. Aje, "The impact of contractors' prequalification on construction project delivery in Nigeria," Eng. Constr. Archit. Manag., vol. 19 no. 2, pp. 159-172, 2012.

[2] A. Movahedian Attar, M. Khanzadi, S. Dabirian, and E. Kalhor, "Forecasting contractor's deviation from the client objectives in prequalification model using support vector regression," Int. J. Proj. Manag., vol. 31, no. 6, pp. 924-936, 2013.

[3] J. R. San Cristóbal, "Contractor Selection Using Multicriteria Decision-Making Methods," J. Constr. Eng. Manag., vol. 138, no. 6, pp. 751-758, 2012.

[4] L. Liu, Y. Zhou, and H. Zhu, "A conceptual framework for vendor selection based on supply chain risk management from a literature,"
J. Syst. Manag. Sci., vol. 1, no. 3, pp. 1-8, 2011

[5] R. A. Khan, "Role of Construction Sector in Economic Growth: Empirical Evidence from Pa," Adv. Interating Constr. Dev. Contries, pp. 279-290, 2008.

[6] G. Ofori, "Nature of the Construction Industry , Its Needs and Its Development : A Review of Four Decades of Research," vol. 20, no. 2, pp. 115-135, 2015.

[7] B. R. Sarker, P. J. Egbelu, T. W. Liao, and J. Yu, "Planning and design models for construction industry: A critical survey," Autom. Constr., vol. 22, pp. 123-134, 2012.

[8] L. Crawford, J. Pollack, and D. England, "Uncovering the trends in project management: Journal emphases over the last 10 years," Int. J. Proj. Manag., vol. 24, no. 2, pp. 175-184, 2006.

[9] Project Management Institute, A guide to the project management body of knowledge (PMBOK ® guide). 2013.

[10] Association for Project Management, Association for Project Management Body of Knowledge, vol. 6th Editio. 2012.

[11] Project Management Institute, Construction Extension to the PMBOK Guide. 2016.

[12] M. S. El-abbasy, T. Zayed, M. Asce, M. Ahmed, H. Alzraiee, and M. Abouhamad, "Contractor Selection Model for Highway Projects Using Integrated Simulation and Analytic Network Process," J. Constr. Eng. Manag., vol. 139, no. 7, pp. 755-767, 2013.

[13] A. Khan, M. S. Lodhi, M. I. Qureshi, I. Naseem, Y. Javed, and K. Zaman, "Management of project changes in construction companies: Case of Pakistan," World Appl. Sci. J., 2014.

[14] P. Jaskowski, S. Biruk, and R. Bucon, "Assessing contractor selection criteria weights with fuzzy AHP method application in group decision environment," Autom. Constr., vol. 19, no. 2, pp. 120-126, 2010.

[15] D. Puri and S. Tiwari, "Evaluating The Criteria f or Contractors ' Selection and Bid Evaluation," Int. J. Eng. Sci. Invent., vol. 3, no. 7, pp. 44-48, 2014.

[16] N. Ibadov, "Contractor selection for construction project, with the use of fuzzy preference relation," Procedia Eng., vol. 111, pp. 317 $323,2015$.

[17] H. Hosseini Nasab and M. Mirghani Ghamsarian, "A fuzzy multiple-criteria decision-making model for contractor prequalification,” J. Decis. Syst., vol. 24, no. 4, pp. 433-448, 2015.

[18] A. Jafari, "A contractor pre-qualification model based on the quality function deployment method," Constr. Manag. Econ., vol. 31, no. 7, pp. 746-760, 2013.

[19] A. Idrus, M. Sodangi, and M. A. Amran, "Decision criteria for selecting main contractors in Malaysia," Res. J. Appl. Sci. Eng. Technol., vol. 3, no. 12, pp. 1358-1365, 2011.

[20] D. J. Watt, B. Kayis, and K. Willey, "The relative importance of tender evaluation and contractor selection criteria," Int. J. Proj. Manag., vol. 28, no. 1, pp. 51-60, 2010.

[21] M. Balubaid and R. Alamoudi, "Application of the Analytical Hierarchy Process (AHP) to Multi-Criteria Analysis for Contractor Selection," Am. J. Ind. Bus. Manag., vol. 5, pp. 581-589, 2015.

[22] R. H. Alias, N. M. M. Noor, M. Y. M. Saman, M. L. Abdullah, and A. Selamat, "Contractor selection using fuzzy comparison judgement," in 2011 5th Malaysian Conference in Software Engineering, MySEC 2011, 2011, pp. 388-392.

[23] B. Somekh and C. Lewin, "Methods in the Social Science," Sage, London, vol. 32, no. 3, pp. 1-15, 2005.

[24] R. V Krejcie and D. W. Morgan, "Determining Sample Size for Research Activities Robert," Educ. Psychol. Meas., vol. 38, no. 1, pp. 607-610, 1970.

[25] W. K. Olsen, Data collection: key debates and methods in social research. London: SAGE Publications, Inc., 2012.

[26] M. Gündüz, Y. Nielsen, and M. Özdemir, "Quantification of Delay Factors Using the Relative Importance Index Method for Construction Projects in Turkey," J. Manag. Eng., vol. 29, no. 2, pp. 133-139, 2012.

[27] N. Aziz et al., "Relative importance index (RII) in ranking of procrastination factors among university students," AIP Conf. Proc., vol. 1761, no. 1, p. 20022, 2016.

[28] H. Doloi, "Analysis of pre-qualification criteria in contractor selection and their impacts on project success," Constr. Manag. 
Econ., vol. 27, no. 12, pp. 1245-1263, 2009

[29] K. A. Pituch and J. P. Stevens, Applied Multivariate Statistics for the Social Sciences. 2016.

[30] K. L. Tiong, Z. Norhayati Mohmad, M. Z. M. Saman, M. S. Md Arif, and A. Z. Bahari, "Implementation of Quality Management System in Malaysian Construction Industry," Adv. Mater. Res., vol. 903, no. November, pp. 359-364, 2014.

[31] M. R. Abdullah, I. A. Rahman, and A. A. A. Azis, "Causes of Delay in MARA Management Procurement Construction Projects," J. Surv. Constr. Prop., vol. 1, no. 1, pp. 123-138, 2010. 